\title{
The Metagenomics and Metadesign of the Subways and Urban Biomes (MetaSUB) International Consortium inaugural meeting report
}

\author{
The MetaSUB International Consortium
}

\begin{abstract}
The Metagenomics and Metadesign of the Subways and Urban Biomes (MetaSUB) International Consortium is a novel, interdisciplinary initiative comprised of experts across many fields, including genomics, data analysis, engineering, public health, and architecture. The ultimate goal of the MetaSUB Consortium is to improve city utilization and planning through the detection, measurement, and design of metagenomics within urban environments. Although continual measures occur for temperature, air pressure, weather, and human activity, including longitudinal, cross-kingdom ecosystem dynamics can alter and improve the design of cities. The MetaSUB Consortium is aiding these efforts by developing and testing metagenomic methods and standards, including optimized methods for sample collection, DNA RNA isolation, taxa characterization, and data visualization. The data produced by the consortium can aid city planners, public health officials, and architectural designers. In addition, the study will continue to lead to the discovery of new species, global maps of antimicrobial resistance (AMR) markers, and novel biosynthetic gene clusters (BGCs). Finally, we note that engineered metagenomic ecosystems can help enable more responsive, safer, and quantified cities.
\end{abstract}

Keywords: Microbiome, Biosynthetic gene clusters, Built environment, Next-generation sequencing, Antimicrobial resistance markers

\section{Introduction}

In the past few years, novel work has characterized the microbiota and metagenome of urban environments and transit systems and demonstrated speciesspecificity to certain areas of a city, "molecular echoes" of environmental events, and even a forensic capacity for geospatial metagenomic data [1-8]. These data are especially helpful for understanding the sites of greatest points of contact between humans and the microbial world within cities, such as their subways or mass-transit systems [1-3, 7]. Indeed, how humans interact with (or acquire) new species of bacteria and other organisms depends on the environment they transit, the types of surfaces they touch, and the physical dynamics of their environment in their city. While a wide variety of methods, protocols,

* Correspondence: chm2042@med.cornell.edu

Dept. of Physiology and Biophysics, Weill Cornell Medicine, New York, NY 10021, USA algorithms, and approaches for such large-scale studies are available for researchers, best practices, normalized methods, and ideal taxonomic approaches for global work are still being developed to ensure data quality and the promotion of robust data interpretation [9-12].

Since the majority of the world's population (54\%) currently resides in cities, the use of integrative functional genomic methods to elucidate the molecular dynamics (DNA, RNA, proteins, and small molecules) and ecosystems of cities has potentially large implications for the sustainability, security, safety, and future planning of cities [13]. This includes the concept of "smart cities," which could detect and respond to pathogens, improve water safety and treatment, and track the ever-changing metagenomic complexity of urban environments [14-17]. Indeed, by establishing a baseline genomic profile for a city, it is then possible to create differentials and density maps of organisms relevant for the built environment, such as 
mold and insects [18], as well as the ability to discern the impact of temperature, pressure, humidity, building materials, and other factors into the movement of organisms across a city. However, integrating the many disparate types of data generated from entire cities requires an interdisciplinary approach bringing together experts in engineering, public health, medicine, architecture, microbiology, metagenomics, bioinformatics, biochemistry, data science, functional genomics, virology, architectural design, and the built environment. Thus, in order to bridge these disciplines and work across cities with global standards and approaches, in 2015, we initiated the Metagenomics and Metadesign of Subways and Urban Biomes (MetaSUB) International Consortium.

Beyond the taxonomic classification and stratification of known and novel species that span a city, these data can be mined for other purposes. This includes characterizing novel markers for antimicrobial resistance (AMR), as well as biosynthetic gene clusters (BGCs), which can discern and validate the small molecules encoded by these organisms' genomes and dynamically regulated transcriptomes $[19,20]$. Since bacteria use small molecules to mediate microbial competition, microbial cooperation, and environment sensing and adaptation, we hypothesize that identifying the suite of small molecules produced by bacteria that are living in urban areas will reveal hidden traits of their adaptation to their successful colonization of variegated surfaces [21]. Several small molecules have been previously isolated from thermophilic and halophilic bacteria, providing a first glance of the metabolic capacity of extremophiles. These include antibacterial molecules, thought to confer a competitive advantage in harsh environments, and siderophores, which act as molecular "scavengers" of trace metals in limited conditions [22, 23]. Thus, MetaSUB's global concerted efforts to map "urban genomes" is not only a window into urban biological systems but also a concomitant search for novel drugs, antibiotics, and small molecules that may provide new avenues for drug development and design.

\section{5 inaugural meeting of the MetaSUB Consortium}

The Inaugural MetaSUB Meeting was sponsored by the Alfred P. Sloan Foundation and held on June 20, 2015, at the New York Genome Center (NYGC), following the Microbes in the City Conference on June 19, 2015, at the New York Academy of Sciences. This represented the first gathering and open meeting of the MetaSUB International Consortium. We had 30 speakers representing a wide array of expertise and disciplines, from microbiology and genomics to building/subway design and metadata collection. The meeting had 139 registrants from over 14 countries, and many speakers and attendants noted that this represented the "coming out of the shadows" of the microbes in our cities and the beginning of using these data to make cities quantified and more integrated [24, 25]. The meeting also featured a key discussion about the promises and pitfalls of metagenomics analysis, including a discussion of some of the first metagenomic data collected in NYC, Hong Kong, and Boston subways $[1-3,26]$.

To organize the goals of the Consortium, five working groups convened, led by five moderators. The sessions included (1) Sample Collection and Metadata led by Lynn Schriml, Ph.D., University of Maryland School of Medicine; (2) Sample Processing and Sequencing led by Daniela Bezdan, Ph.D., Center for Genomic Regulation in Spain; (3) Bioinformatics Analytics led by Brian Kidd, Ph.D., Icahn School of Medicine at Mount Sinai; (4) Visualization and Interpretation led by Elizabeth Hénaff, Ph.D., Weill Cornell Medicine; and (5) Ethical and Social Challenges led by Nathan Pearson, Ph.D., New York Genome Center. The summaries of these discussions have been outlined below and are also posted on the study's website (www.metasub.org). The results of these working group discussions have built the foundations of MetaSUB, as each working group dealt with a key challenge the MetaSUB consortium will have to address with this global study. These working groups will evolve into committees that members of the consortium can sit on and lead. All the work by these committees will be reviewed by an external advisory board (EAB) made up of experts in the fields of bioinformatics, virology, microbiology, immunology, genomics, and mass transit. This includes Elodie Ghedin, Ph.D., New York University, Timothy Read, Ph.D., Emory University, Claire Fraser, Ph.D., University of Maryland School of Medicine, Joel Dudley, Ph.D., Icahn School of Medicine at Mount Sinai, Mark Hernandez, PE, Ph.D., University of Colorado, and Christopher Bowle, Ph.D., Institut de Biologie de l'Ecole Normale Supérieure.

\section{Summary of key points from working groups Sample collection and metadata}

Any large-scale collection effort requires a detailed protocol and test of best practices, which was a key focus of the meeting. The discussion highlighted a number of challenges and suggestions related to sampling methods, standardization of protocols for data collection and processing, and validation and comparability of metadata. Also, some of the questions regarding MetaSUB collections spanned a range of unknown aspects of urban microbiomes. This ranged from the regularity of metagenomic species compositions (across time and space), the sensitivity of a surface to harboring bacteria or DNA in the context of weather, temperature, humidity, usage, and other metadata, the thresholds for persistence, the 
biochemical and biological functions of organisms as a function of their location, and the different methods for air vs. surface collection. The significant results of this working group are the following:

- There should be a standardized protocol for sampling across all the MetaSUB cities, reducing variability, as has been done for the FDA's Sequencing Quality Control Consortium, the Genome in a Bottle Consortium, and the Metagenomics Standards Groups like the Earth Microbiome Project [9, 10, 27-30].

- Several series of controlled experiments should be conducted to determine what factors impact the quality of the samples, specifically, the DNA yield and potentially diversity of samples (e.g., number of passengers, humidity, air flow, temperature, sampling devices, sample storage)

- Establish a standard way to assess cleaning treatment of the different subway systems.

- Both surface-based and air sampling should be conducted in each of the city transit systems.

- The sampling protocol and metadata selection should be based on a hypothesis-driven and question-based approach that can be uniform across all cities.

- Design the most effective and efficient data collection application ("app") that will be functional in all cities, store the metadata, upload it onto a web database, and integrate with geospatial data to create a map of collections. These include the fields of Table 1.

\section{Sample processing and sequencing}

A key challenge in metagenomic studies is to obtain a representative picture of heterogeneous environmental samples and to avoid sample processing-based biases when comparing samples collected at different sites and time points. In theory, DNA isolated from a metagenomic sample should represent the biodiversity in complex populations. In reality, the quality of the information that can be generated and analyzed is highly dependent on how the samples have been collected, stored, and processed. Therefore, the goal of this working group is to (1) define standards for sample swabbing, storage, DNA extraction, sequencing library preparation and sequencing, (2) benchmark available sample processing methods, (3) survey the reproducibility of protocols at different centers, and (4) communicate defined standards to MetaSUB collaborators and the public. To this end, advantages, limitations, and potential issues of available swabbing, DNA extraction, and library preparation methods need to be investigated, and candidate methods need to be benchmarked on diverse sample types.

Table 1 Data fields for MetaSUB mobile data collection

\begin{tabular}{|c|c|c|}
\hline Category & \# of fields & Fields, with input from OSBSS metadata \\
\hline MetaSUB data type & 15 & $\begin{array}{l}\text { Soil, Superfund site, waterway, land/sea/air interface, subway, marine wild-life, synthetic } \\
\text { ecologies, cockroach, bedbug, pigeon, rat, worm, lab mice, NYC homes, sewage }\end{array}$ \\
\hline Surface composition & 9 & Metal, wood, plastic, ceramic, leather, concrete, glass, other \\
\hline Surface type & 8 & Kiosk, turnstile, bench, railing, handrail, garbage can, payphone, other \\
\hline Surface porosity & 3 & Hermetically sealed, porous, absorbent \\
\hline Cleaning frequency & 1 & Frequency per day \\
\hline Cleaning type & 1 & Text for detergent or methods used \\
\hline Human activity & 3 & Video, IR, and observational estimates of \# of people \\
\hline Air vents & 3 & Number of input and output vents \\
\hline Subway lines & 22 & $1,2,3,4,5,6,7, A, C, E, B, D, F, M, G, J, Z, L, S, N, Q R$ \\
\hline Subway stations & 468 & Auto-complete from form \\
\hline Subway car position & 3 & First car, $\mathrm{N}+$ I car, last car \\
\hline Train ID & 1 & Train\# 4673 \\
\hline Temperature & 1 & Range from $-50^{\circ} \mathrm{F}$ to $15 \mathrm{CTF}$ \\
\hline Humidity & 1 & Range from 0 to $100 \%$ \\
\hline Park surfaces & 9 & Bench, handrailing, water fountain, slide, monkey bars, swings, trash can, lamp post, other \\
\hline Audio & 3 & Record, play, delete \\
\hline Geotag and time & 1 & GPS-coordinates (longitude and latitude) and time-stamp \\
\hline Photograph & 1 & iOSor android-based \\
\hline
\end{tabular}


A main issue for sample processing is the heterogeneity of environmental samples. MetaSUB swabs will differ in DNA content and quality as well as microbiome composition, i.e., contain variable fractions of gramnegative and gram-positive bacteria, viral, fungi, and other populations of organisms. Variable susceptibility of cell structures to lytic reagents will introduce biases during DNA extraction. In addition, many microorganisms are present in the form of spores, which demonstrate high resistance to lytic practices [31]. The heterogeneous sample aggregates will range from solid to liquid, and are in most cases temperature, $\mathrm{pH}$, and oxygen sensitive. Therefore, it is crucial to take parameters of the sample habitat and conditions like temperature, $\mathrm{pH}$, or salinity into account for optimal selection of sample processing and library preparation methods (see Table 1 for collected data fields) or to account for introduced biases during statistical analysis of the sequencing data.

\section{Sample swabbing and storage}

Since cotton swabs could lead to significant contamination with cotton DNA during extraction, we first concluded that plant-based collection media would be avoided. Thus, collections should use the previouslyutilized, nylon-flocked swabs (Copan Liquid Amies Elution Swabs 480C), retained in $1 \mathrm{ml}$ transport medium. Minimal generation times of microorganisms range from a few minutes to several weeks [32]. Therefore, to avoid growth bias, environmental samples should be kept on ice during transportation to preserve their initial species composition. Samples are stored at $-20{ }^{\circ} \mathrm{C}$ or below. Workbenches and non-sterile materials must have been cleaned with bleach and ethanol to avoid any cross-contamination.

\section{DNA extraction}

Two ways to extract DNA have been proposed: (1) direct extraction of DNA in situ by lysis of the bacterial cells within the sample and (2) indirect extraction by separation of bacterial cells from other organic and inorganic materials followed by DNA extraction. One of the main disadvantages of the direct extraction methods is the elevated risk of contamination with humic acids, proteins, polysaccharides, lipids, minerals, non-bacterial DNA, and minerals. Those contaminations can be difficult to remove and can inhibit chemical and enzymatic steps required for DNA processing and library preparation. On the other hand, the indirect extraction of DNA by extraction of bacterial cells from the sample likely leads to an incomplete representation or bias in content measures of bacterial species within the sample [33]. Thus, MetaSUB currently plans to use direct DNA extraction protocols, such as MoBio PowerSoil kit.
However, we will also compare and test various extraction protocols, combining mechanical, chemical, and enzymatic lyses steps for the several reasons. Mechanical methods like bead-beating homogenizations, sonification, vortexting, and thermal treatments like freezingthawing or freezing-boiling tend to yield the most comprehensive access to DNA from the whole bacterial community as they allow to expose DNA from bacteria in micro-aggregates and spores. Extensive physical treatment could lead to DNA shearing resulting in fragments ranging from 600 to $12 \mathrm{~kb}$, which, while not a problem for short fragment sequencing techniques (e.g., Illumina HiSeq) but would be problematic for long-read technologies (e.g., Pacific Biosciences, Oxford Nanopore MinION). Chemical cell disruption by detergents is another widely used technique. The most commonly employed chelating agents are SDS, EDTA, Chelex 100, and various Tris- and Natrium phosphate buffers. Other chemical reagents like cetyltrimethyl-ammonium bromid (CTAB) are able to remove humic acid to some extend. Humic acid contaminations are problematic since they share similar chemical and physical characteristics like DNA and co-purified humic acids also interferes with the DNA quantification, since they exhibit absorbance between 230 and $260 \mathrm{~nm}$ as well. Finally, enzymatic methods complement mechanical and chemical techniques by disrupting cell walls of gram-positive bacteria, which tend to be resistant to physical stress. In addition, they facilitate removal of RNA and protein contaminations, even though single-stranded and double-standed RNA viruses are an important component of the metagenomic profiles (ongoing efforts are being to made to get all of these as well). Most commonly used enzymes are lysozymes, RNase, and proteinase K (2015). Currently, members of the consortium are testing a new enzyme cocktail for DNA extraction consisting of lysozyme, mutanolysin, achromopeptidase, lysostaphin, chitinase, and lyticase (Fig. 1), which so far show improved yields across multiple commonly used kits for metagenomics extraction.

\section{Sequencing library preparation}

The current gold standard for metagenomic sequencing is based on paired-end sequencing on the Illumina HiSeq (2500 or 4000) using 100 to 150 bp paired reads. Longer reads of up to $300 \mathrm{bp}$ as produced by the MiSeq increase specificity of read alignments and hence improve identification of bacterial species. However, the substantial increase in per-base cost of sequencing leads to lower depth-of-coverage and can dramatically reduce the detectability of bacterial populations contained in very small fractions. Long-read sequencing technologies (Pacific Bioscience SMRT and Oxford Nanopore MinION) promise to substantially improve classification 


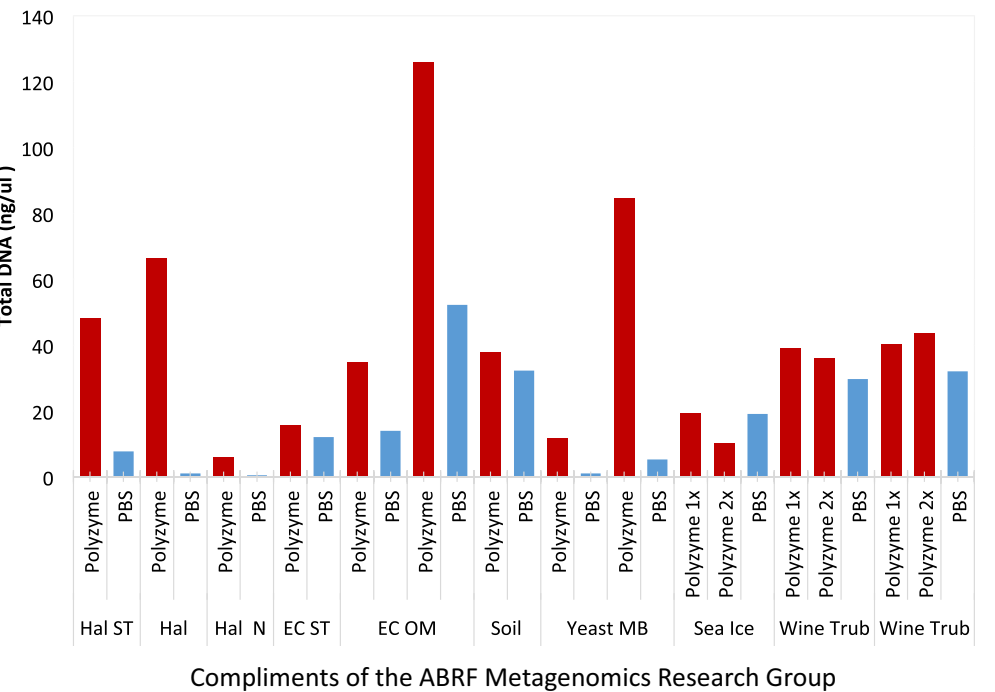

Fig. 1 Performance of new metagenomics enzyme cocktail. We used replicate samples for a range of different extraction kits with (red) and without (blue) the polyzyme mixture ( $x$-axis) and examined the yield of DNA from the extraction (y-axis). Samples include Halobacillus (Ha), Escherichia coli (EC), soil samples, yeast, sea ice, and a wine trub for the Omega Mullusc Kit (OM), Norgen Soil Kit ( $M$ ), and the Standard CTAB-Phenol protocol (ST)

of bacterial DNA by simplifying de novo assembly of novel species and by allowing to span complete operons and bridging long repeats with a single read. The Roche 454 platform, which has been a cornerstone of metagenomics in several studies, has not been considered here, as the technology has been discontinued. Based on these considerations, we concluded that all MetaSUB samples will be sequenced using the Illumina HiSeq platform and $150 \mathrm{bp}$ paired-end reads. The application of longread technologies will be tested on a subset of samples, and results will be benchmarked based on short read results. Finally, the inclusion of a positive control sample with known bacterial and metagenomic samples present was recommended, such as those from the Genome Reference Consortium (GRC) and US National Institute of Standards and Technology (NIST).

\section{Bioinformatics analytics}

With the advent of citizen science, crowdsourcing, and participatory international coordination of sampling, the ability to collect large metagenomic datasets from our surroundings is no longer the limiting factor in scientific discovery and exploration of the microbial landscape in urban environments [35]. As the tide has shifted, key questions about ideal methods to analyze and process the data have become paramount, and multiple analytical challenges have arisen for computing, processing, and sharing of metagenomic data [12]. Addressing these analytical challenges has implications for how we understand and interpret the diversity and complexity of urban biomes. The bioinformatics working group discussed current analytical challenges facing the consortium and suggests protocol adaptations as technologies improve. What emerged from the discussion were four themes covering (1) standards, (2) reproducibility, (3) openaccess/data sharing, and (4) innovation. The central goal of the bioinformatics working group is to build on these themes over time, refining the methods, because as it currently stands, there is not a definitive set of guidelines for many of these challenges.

\section{Sample standardization for benchmarking analytical tools and interpreting results}

A key challenge in analyzing metagenomic sequences from urban environments is how to deal with potential novelty and sequence diversity. Metagenomic sequencing provides an unprecedented wealth of data, and probing the urban biome pushes the frontiers of our knowledge and understanding of microbes. It is thus critical to have empirical and computational standards to delineate the technical issues from true discoveries. An empirical way to address this challenge is to extraneously introduce standard control samples that have been well characterized to help interpret findings and place discoveries in context. Another approach is to generate reference data sets from various sequencing technologies that bioinformaticians and developers can use for testing and benchmarking [34]. These reference sequence sets provide ideal test cases for understanding technical issues with sequencing data or algorithms (given the known proportions of various bacteria) and supply useful benchmarks for consortium members during the development of new tools [1]. More importantly, these references serve as standards for developing clear 
metrics on how to evaluate and interpret results from metagenomic analyses from large numbers of people [35].

\section{Data processing and reproducibility}

The massive scale and volume of metagenomic data generated in studies of the urban biome exceeds our ability to conduct manual processing and quality assurance. Computational processing can alleviate this bottleneck, and it is important to develop clear quality control metrics for each link in the analytical chain (data QC, post-sequencing trimming, alignment, assembly, phylogenetics, summary statistics). As sample preparation and processing strongly influence what information can be extracted and analyzed, it is important to have strong collaborations between the computational biologists who develop the computational tools and the core facilities or labs that create the libraries and process samples for sequencing, as well as methods to detect, and correct, for batch effects [36].

Code sharing and transparency are important features of reproducibility, and open source tools such as R and Bioconductor exist for creating processing pipelines. It is important to create transparent workflows that can be cloned and deployed on remote machines so the analyses can be reproduced with minimal effort [37]. Furthermore, electronic notebooks with protocols can be linked with publications. Having version control or Docker-style tracking encourages collaboration and enables best practices to spread through the community of developers and scientists. Other large-scale consortiums such as The Cancer Genome Atlas (TCGA) and Human Microbiome Project (HMP) have successfully navigated these issues and provided a model for creating accessible data portals with community-based tools [38, 39]. In this age of abundant computing and storage, data provenance and transparency are critical for developing robust and useful methods that enable innovation while maintaining scientific rigor.

\section{Data sharing and common formats}

Collecting samples and generating data can be an expensive effort, yet these data sets are rich and can be leveraged when others have access to data. As a community, we want to encourage open collaboration and provide incentives for researchers to share their published data in a common format that facilitates interoperability (e.g., SAGE, HMP guidelines). We can better understand how microarray technology has matured and the data warehouses that have sprung up around the developing technology. Central clearing houses like the Gene Expression Omnibus (GEO) and European Genome-phenome Archive (EGA) include standard data fields and associated metadata that are compliant with Minimum Information
About a Microarray Experiment (MIAME) guidelines [40-42]. These resources have accelerated research and collaborations by providing accessible data sets for developing novel methods and addressing new scientific questions, which are linked with the original contribution [43]. Additionally, the analysis of public data has generated many new insights and hypotheses that would not have been identified or proposed otherwise [44]. Ideally, these data sharing portals offer ways to link new insights and results back to their original source. These data warehouses establish a strong foundation for other scientists, citizens, and policy makers to develop new research strategies based on the accumulated knowledge.

\section{Innovation}

Technological and computational innovations will continue to define and drive investigations of urban biomes across all MetaSUB sites (Table 2). These advances create an apparent tension between being the cutting edge where analyses and conclusions are more fluid, and wellestablished processes that are robust and strongly supported. It is crucial to distinguish between these two modes and the computational tools that underpin them. We want to encourage the development of novel methods and work toward best practices that result in accepted pipelines that serve as a strong foundation for scientific discovery.

\section{Data visualization and interpretation}

Visualization and interpretation are some of the most challenging aspects of a study this large and global. Thus, the working group outlined the goals of the consortium according to three main areas. First, there is a need to design systems of data visualization for data exploration, so that any user of the web site or resources can rapidly learn from and utilize the data [1]. Second, there must be a clear outline of the consortium organization (Fig. 2), including an ability to look at results, metadata, and milestones for each city. Third, there is a need for communicating results, collaboration, publications, and the status of outreach and citizen science efforts. This will continue to use the components of web sites, online forums, and social media such as Twitter, Facebook, and Instagram.

Each of these categories holds its own challenges and specifications, for example, visualizations for data exploration need to be much denser in information than for publication where only the information relevant to the message needs to be presented. Visualizations for outreach need to be friendly and easy to understand by non-scientists and laypeople. The medium available also influences design choices: figures designed for print media have limitations that the web does not, and we have already piloted a cross-kingdom browser for urban 
Table 2 Hub laboratories of the MetaSUB International Consortium

\begin{tabular}{|c|c|c|c|c|c|c|}
\hline \multirow[b]{2}{*}{ Site } & \multicolumn{2}{|l|}{ City details } & \multicolumn{4}{|l|}{ Site principal investigator } \\
\hline & City & Country & Department & University/institute & Contact Pls & Email \\
\hline 1 & Buenos Aires & Argentina & $\begin{array}{l}\text { 1. Genetics and Genomic Sciences; } 2 \\
\text { Computational Biology Center; } 3 . \\
\text { Departamento de Fisica }\end{array}$ & $\begin{array}{l}\text { 1. Icahn School of Medicine at Mount } \\
\text { Sinai; } 2 \text { IBM; } 3 \text {. University of Buenos Aires }\end{array}$ & $\begin{array}{l}\text { Gustavo Stolovitzky }{ }^{1,2} / \text { Ariel } \\
\text { Chernonetz }{ }^{3}\end{array}$ & $\begin{array}{l}\text { gustavo@us.ibm.com/achernomoretz@ } \\
\text { leloir.org.ar }\end{array}$ \\
\hline 2 & Sydney & Australia & Computational Metagenomics & University of Technology & Aaron Darling/Catherine Burke & $\begin{array}{l}\text { aaron.darling@uts.edu.au/Catherine. } \\
\text { Burke@uts.edu.au }\end{array}$ \\
\hline 3 & Vienna & Austria & Bioinformatics/Bioinformatics & $\begin{array}{l}\text { Boku University Vienna/University of } \\
\text { Applied Sciences }\end{array}$ & Paweł P. Łabaj/Alexandra Graf & $\begin{array}{l}\text { pawel.labaj@boku.ac.at/alexandra. } \\
\text { graf@fh-campuswien.ac.at }\end{array}$ \\
\hline 4 & Ribeirão Preto & Brazil & $\begin{array}{l}\text { Department of Genetics, Laboratory of } \\
\text { Epigenomics and Bioinformatics }\end{array}$ & University of Sao Paolo & Houtan Noushmehr & houtan@usp.br \\
\hline 5 & Rio Da Janeiro & Brazil & Oswaldo Cruz Institute & FIOCRUZ & Milton Ozorio Moraes & milton.moraes@fiocruz.br \\
\hline 6 & São Paulo & Brazil & Medical Genomics & AC Camargo Cancer Center & Emmanuel Dias-Neto & emmanuel@cipe.accamargo.org.br \\
\hline 7 & Santiago & Chile & & Universidad del Desarrollo & Juan Ugalde & jugalde@udd.cl \\
\hline 8 & Beijing & China & $\begin{array}{l}\text { Beijing Children's Hospital/Translational } \\
\text { Bioinformatics Research Institute }\end{array}$ & Capital Medical University/Capitalbio Corp & Yongli Guo/Yiming Zhou & $\begin{array}{l}\text { ylgyongliguo@163.com/yimingzhou@ } \\
\text { capitalbio.com }\end{array}$ \\
\hline 9 & Guangzhou & China & $\begin{array}{l}\text { 1. Zhongshan ophthalmic Center, } \\
\text { Center for Precision Medicine; } \\
\text { 2. Department of Environmental Health; } \\
\text { 3. Division of Laboratory Medicine at } \\
\text { Zhujiang Hospital }\end{array}$ & $\begin{array}{l}\text { 1. Sun Yat-sen University; 2.Southern } \\
\text { Medical University }\end{array}$ & $\begin{array}{l}\text { Zhi Xie1,1/Daisy Zheng2,2/ } \\
\text { Hongwei Zhou2,3 }\end{array}$ & $\begin{array}{l}\text { xiezhi@gmail.com/180553957@qq.com/ } \\
\text { 811807859@qq.com }\end{array}$ \\
\hline 10 & Hong Kong & China & School of Energy and Environment & City University of Hong Kong & Patrick K.H. Lee & patrick.kh.lee@cityu.edu.hk \\
\hline 11 & Shanghai & China & School of Life Science & Fudan University & $\begin{array}{l}\text { Leming Shi/Sibo Zhu/Anyi } \\
\text { Tang }\end{array}$ & $\begin{array}{l}\text { lemingshi@fudan.edu.cn/sibozhu@fudan. } \\
\text { edu.cn/491269854@qq.com }\end{array}$ \\
\hline 12 & Bogota & Colombia & Molecular Genetics & Corporación Corpogen & $\begin{array}{l}\text { Carlos A. Ruiz-Perez/Maria M. } \\
\text { Zambrano }\end{array}$ & $\begin{array}{l}\text { cruiz_perez@hotmail.com/mzambrano@ } \\
\text { corpogen.org }\end{array}$ \\
\hline 13 & Zagreb & Croatia & Department of Microbiology & University of Zagreb & Tomislav Ivanković & tomislav.ivankovic@biol.pmf.hr \\
\hline 14 & Cairo & Egypt & Department of Biology & American University of Cairo & Rania Siam & rsiam@aucegypt.edu \\
\hline 15 & Marseille & France & Department of Virology & Aix-Marseille University & Nicolas Rascovan & nicorasco@gmail.com \\
\hline 16 & Paris & France & $\begin{array}{l}\text { Laboratory of Computational and } \\
\text { Quantitative Biology }\end{array}$ & $\begin{array}{l}\text { Sorbonne Universite's, University Pierre et } \\
\text { Marie Curie Univ. Paris 06, CNRS, Institut } \\
\text { de Biologie Paris-Seine }\end{array}$ & $\begin{array}{l}\text { Hugues Richard/Ingrid } \\
\text { Lafontaine }\end{array}$ & $\begin{array}{l}\text { hugues.richard@upmc.fr/ingrid. } \\
\text { lafontaine@upmc.fr }\end{array}$ \\
\hline 17 & Berlin & Germany & Public Health & Robert Koch Institute & $\begin{array}{l}\text { Lothar H. Wieler/Torsten } \\
\text { Semmler }\end{array}$ & wielerlh@rki.de/SemmlerT@rki.de \\
\hline 18 & Hyderabad & India & $\begin{array}{l}\text { Department of Biotechnology and } \\
\text { Bioinformatics }\end{array}$ & $\begin{array}{l}\text { University of Hyderabad/Noble Foundation/ } \\
\text { ClonzBio Tech }\end{array}$ & $\begin{array}{l}\text { Niyaz Ahmed/Bharath } \\
\text { Prithiviraj/Narasimha Nedunuri }\end{array}$ & $\begin{array}{l}\text { ahmed.nizi@gmail.com/bharath. } \\
\text { prithiviraj@gmail.com/narasimha. } \\
\text { nedunuri@clonzbio.com }\end{array}$ \\
\hline 19 & New Delhi & India & Computational Biology & Memorial Sloan Kettering & Sikander Hyat & hayat221@gmail.com \\
\hline
\end{tabular}


Table 2 Hub laboratories of the MetaSUB International Consortium (Continued)

\begin{tabular}{|c|c|c|c|c|c|c|}
\hline 20 & Tehran & Iran & Ecology/Medical Sciences & $\begin{array}{l}\text { American Museum of Natural History/ } \\
\text { Ministry of Science }\end{array}$ & $\begin{array}{l}\text { Shaadi Mehr/Kambiz } \\
\text { Banihashemi }\end{array}$ & $\begin{array}{l}\text { smehr@amnh.org/kbanihashemi@ } \\
\text { yahoo.com }\end{array}$ \\
\hline 21 & Rome & Italy & Molecular Biology Section & $\begin{array}{l}\text { Army Medical and Veterinary Research } \\
\text { Center }\end{array}$ & Florigio Lista/Anna Anselmo & $\begin{array}{l}\text { romano.lista@gmail.com/ } \\
\text { annanselm@gmail.com }\end{array}$ \\
\hline 22 & Sendai & Japan & Institute for Advanced Biosciences & Keio University & Haruo Suzuki & haruo@sfc.keio.ac.jp \\
\hline 23 & Tokyo & Japan & Institute for Advanced Biosciences & Keio University & Haruo Suzuki & haruo@sfc.keio.ac.jp \\
\hline 24 & Mexico City & Mexico & National Institute of Public Health & IANPHI Mexico Secretariat & $\begin{array}{l}\text { Celia M. Alpuche Aranda/Jesus } \\
\text { Martinez }\end{array}$ & $\begin{array}{l}\text { celia.alpuche@insp.mx/jmbarnet@ } \\
\text { insp.mx }\end{array}$ \\
\hline 25 & $\begin{array}{l}\text { Auckland, } \\
\text { Hamilton and } \\
\text { Rotorua }\end{array}$ & $\begin{array}{l}\text { New } \\
\text { Zealand }\end{array}$ & Environmental Research Institute & Univeristy of Waikato & Ayokunle Christopher Dada & cdada@waikato.ac.nz \\
\hline 26 & Lagos & Nigeria & Microbiology & University of Lagos & Folarin Oguntoyinbo & foguntoyinbo@unilag.edu.ng \\
\hline 27 & Oslo & Norway & $\begin{array}{l}\text { Protection and Societal Security } \\
\text { Division }\end{array}$ & $\begin{array}{l}\text { Norwegian Defense Research } \\
\text { Establishment FFI }\end{array}$ & Marius Dybwad & marius.dybwad@ffi.no \\
\hline 28 & Lisbon & Portugal & $\begin{array}{l}\text { Department of Biology, i3S Population } \\
\text { Genetics and Evolution Group }\end{array}$ & University of Porto & $\begin{array}{l}\text { Manuela Oliveira/Andreia } \\
\text { Fernandes }\end{array}$ & $\begin{array}{l}\text { manuelao@ipatimup.pt/afernandes@ } \\
\text { ipatimup.pt }\end{array}$ \\
\hline 29 & Porto & Portugal & $\begin{array}{l}\text { Department of Biology, i3S Population } \\
\text { Genetics and Evolution Group }\end{array}$ & University of Porto & $\begin{array}{l}\text { Manuela Oliveira/Andreia } \\
\text { Fernandes }\end{array}$ & $\begin{array}{l}\text { manuelao@ipatimup.pt/afernandes@ } \\
\text { ipatimup.pt }\end{array}$ \\
\hline 30 & Doha & Qatar & Ecology/Medicine & Weill Cornell Medical College - Qatar & $\begin{array}{l}\text { Aspassia D. Chatziefthimiou/ } \\
\text { Salama Chaker }\end{array}$ & $\begin{array}{l}\text { a.chatziefthimiou@richenvironments.com } \\
\text { salama.b.chaker@gmail.com }\end{array}$ \\
\hline 31 & Moscow & Russia & Bioinformatics & $\begin{array}{l}\text { Moscow Institute of Physics and } \\
\text { Technology, Institutskii Per. 9, Moscow } \\
\text { Region, Dolgoprudny 141700, Russia }\end{array}$ & $\begin{array}{l}\text { Dmitry Alexeev/Dmitry } \\
\text { Chuvelev }\end{array}$ & alexeev@knomics.ru/dch@knomics.ru \\
\hline 32 & Singapore & Singapore & Biochemistry and Molecular Biology & Pennsylvania State University & Stephan Schuster & scschuster@ntu.edu.sg \\
\hline 33 & Johannesburg & $\begin{array}{l}\text { South } \\
\text { Africa }\end{array}$ & Data Driven Healthcare & IBM Research-Africa & Geoffrey H Siwo & gsiwo@za.ibm.com \\
\hline 34 & Seoul & $\begin{array}{l}\text { South } \\
\text { Korea }\end{array}$ & $\begin{array}{l}\text { Microbiology/Institute for Allergy and } \\
\text { Immunology/Cancer Risk Appraisal \& } \\
\text { Prevention Branch }\end{array}$ & $\begin{array}{l}\text { Institut Pasteur Korea/Korea University } \\
\text { College of Medicine/National Cancer } \\
\text { Center }\end{array}$ & $\begin{array}{l}\text { Soojin Jang/Sung Chul Seo/ } \\
\text { Sung Ho Hwang }\end{array}$ & $\begin{array}{l}\text { soojin.jang@ip-korea.org/sungchul_ } \\
\text { seo@korea.ac.kr/9954074@daum.net }\end{array}$ \\
\hline 35 & Barcelona & Spain & Genomic and Epigenomic Variation & $\begin{array}{l}\text { 1. Center for Genomic Regulation (CRG), } \\
\text { The Barcelona Institute of Science and } \\
\text { Technology, Dr. Aiguader } 88 \text {, Barcelona } \\
08003 \text {, Spain 2. Universitate Pompeu } \\
\text { Fabra (UPF), Barcelona, Spain }\end{array}$ & $\begin{array}{l}\text { Stephan Ossowski1,2/Daniela } \\
\text { Bezdan1,2 }\end{array}$ & $\begin{array}{l}\text { Stephan.Ossowski@crg.eu/bezdan. } \\
\text { daniela@googlemail.com }\end{array}$ \\
\hline 36 & Stockholm & Sweden & $\begin{array}{l}\text { Department of Molecular Biosciences, } \\
\text { The Wenner-Gren Institute }\end{array}$ & Stockholm University & Klas Udekwu/Per O. Lungjdahl & klas.udekwu@su.se/per.ljungdahl@su.se \\
\hline 37 & Zurich & Switzerland & Institute of Molecular Life Sciences & University of Zurich & Olga Nikolayeva & olga.nikolayeva@gmail.com \\
\hline 38 & Izmir & Turkey & $\begin{array}{l}\text { Department of Biostatistics and Medical } \\
\text { Informatics }\end{array}$ & Acibadem University & Ugur Sezerman & sezermanu@gmail.com \\
\hline 39 & Sheffield & UK & Department of Animal \& Plant Sciences & University of Sheffield & Eran Elhaik & e.elhaik@sheffield.ac.uk \\
\hline
\end{tabular}


Table 2 Hub laboratories of the MetaSUB International Consortium (Continued)

\begin{tabular}{|c|c|c|c|c|c|c|}
\hline 40 & Montevideo & Uruguay & Informatik & ETH Zurich & Gaston Gonnet & gonnet@ethz.ch \\
\hline 41 & Baltimore & USA & Institute for Genome Sciences & $\begin{array}{l}\text { University of Maryland School of } \\
\text { Medicine }\end{array}$ & Emmanuel Mongodin & emongodin@som.umaryland.edu \\
\hline 42 & Boston & USA & Biostatistics & $\begin{array}{l}\text { Harvard T.H. Chan School of Public } \\
\text { Health }\end{array}$ & Curtis Huttenhower & chuttenh@hsph.harvard.edu \\
\hline 43 & Chicago & USA & Microbial Ecology & Argonne National Laboratory & Jack Gilbert & gilbertjack@uchicago.edu \\
\hline 44 & Denver & USA & Mechanical Engineering & University of Colorado & Mark Hernandez & mark.hernandez@colorado.edu \\
\hline 45 & Fairbanks & USA & Institute of Arctic Biology & University of Alaska Fairbanks & Elena M. Vayndorf & elena.vayndorf@alaska.edu \\
\hline 46 & New York City & USA & Physiology and Biophysics & Weill Cornell Medicine & Christopher Mason & chm2042@med.cornell.edu \\
\hline 47 & Sacramento & USA & Department of Ecology and Evolution & UC Davis & Jonathan Eisen & jonathan.eisen@gmail.com \\
\hline 48 & San Francisco & USA & $\begin{array}{l}\text { Department of Interdisciplinary Arts and } \\
\text { Sciences }\end{array}$ & University of California, Davis & Christopher Beitel & chris.w.beitel@gmail.com \\
\hline 49 & Seattle & USA & Department of Genetics and Genomics & University of Washington & David Hirschberg & dhberg@uw.edu \\
\hline 50 & Washington DC & USA & Institute for Genome Sciences & $\begin{array}{l}\text { University of Maryland School of } \\
\text { Medicine }\end{array}$ & Lynn Schriml & Ischrim|@som.umaryland.edu \\
\hline 51 & London & UK & Department of Twin Research & Kings College London & Frank Kelly/Sarah Metrustry & $\begin{array}{l}\text { frank.kelly@kcl.ac.uk/sarah.metrustry@ } \\
\text { kcl.ac.uk }\end{array}$ \\
\hline
\end{tabular}

We show the city, country, site of collaboration (university, company, or government agency), principal investigator (PI), and the number of riders per year in the targeted mass-transit system. This includes the top busiest subways in the world, except for Moscow (still recruiting PI) 


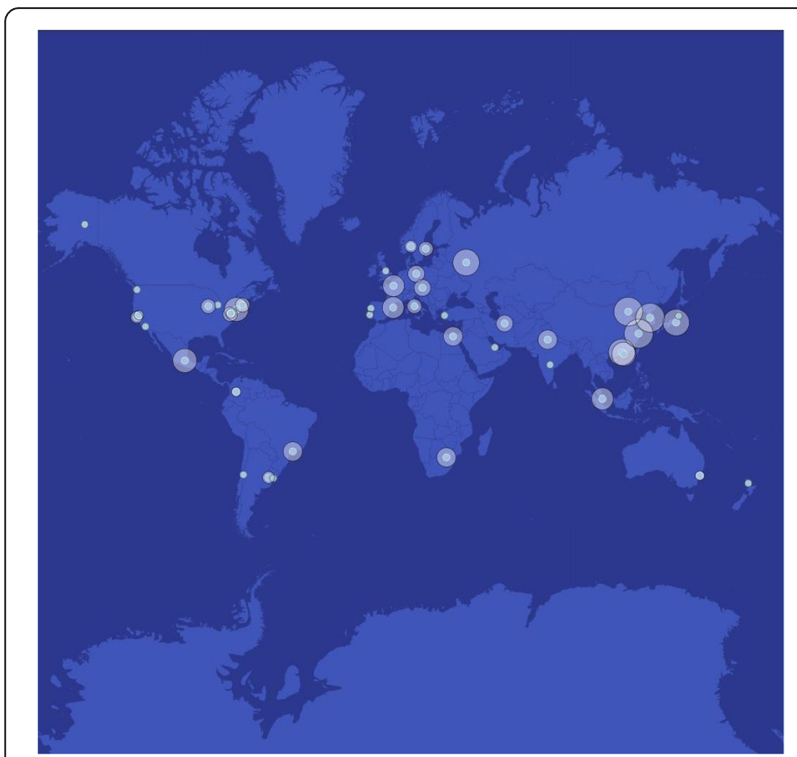

Fig. 2 Map of active MetaSUB sites. We have shown all the sites of the MetaSUB International Consortium that are collecting. The sizes of the circles are proportional to the number of riders per year on the subway or mass-transit system

metagenomics (www.pathomap.org/map) [1]. In addition to visualizing scientific data, we will use visual representations to aid in the coordination and organization of the consortium, e.g., metadata regarding the number of samples collected and processed in each site. Finally, the kind of data will dictate the design of the visualizations. Such data include metadata taxa present (phylogenetic relationships and abundance), metabolic pathways, functional annotations, geospatial relationships, and timelapse data. Finally, metadata outlined in Table 1 will also be integrated into the design of these visuals, since the metadata from a study can readily become the raw data for a follow-up study.

\section{Ethical, social, and legal challenges}

Since the MetaSUB Consortium is a public, transparent, and open consortium that aims to characterize and discover the microbial sides of the cities in which we live, transparency is an important principle during the process of urban biome discovery, hands-on education, and city planning. Therefore, all meeting minutes, talk slides, and group listserv correspondences are posted in public archives and also on the Consortium website. Also, any grant dollars, donations, and corporate sponsorship are listed and detailed publicly as well.

Nonetheless, there are several critical ethical and social challenges that must be addressed. First, the collection of samples must be done in a transparent and assuring fashion, and work from the first studies included business cards to hand out to citizens on the street for when they had questions. Interactions from the public ranged from curiosity and extreme interest about the project to confusion of what would be found. In general, because the first data sets have shown a predominance of harmless and commensal bacteria, it is important to note the data-based assurance to the public safety and trust in public transportation. Nonetheless, there have been lessons learned from the "cautionary tale" of DNA found in NYC metagenomic data sets [12], wherein fragments of DNA that matched a pathogen must be put into the context of virulence markers and also in the context of likelihood of the samples being present. Finally, these first urban metagenome reports also show that the collection, interpretation, and release of such public data represent an extremely serious responsibility for the scientists reporting and interpreting these sensitive data.

Also, consideration of other logistical challenges related to the interpretation and release of the data and analysis are required, regarding city, transit, and health authorities in each city. Some cities may wait until data are published before deciding to comment, but nonetheless, all data and manuscripts should be shared with city officials beforehand, and this has been the standard applied thus far [1]. Also, three new guidelines have been implemented as part of MetaSUB: all data and sequences collected will be given to the local authorities for a "Right to First Review," before any publication or presentation of these results to the public, due to the potential sensitivity of some of the species that may be discovered. Protocols will follow internationally recognized standards for quality control and sequencing rigor from the US Food and Drug Administration's (FDA) Sequencing Quality Control Consortium (SEQC) and the Earth Microbiome Project (EMP) as outlined above. Any species discovered that are germane to bioterrorism or public health will be turned over to public health officials first and not reported without independent validation.

Finally, the ability to "mine" the metagenomic biological data for new drugs, small molecules, and antibiotics brings additional possibilities for innovation, but also complications (Fig. 3). Since each country has their own guidelines surrounding intellectual property (IP), ownership of biological data, and also the regulations around "bio-prospecting," care must be taken to ensure that national and international guidelines for collection are met. Most current legislation around the world define "prospecting" as the collection of samples and removal from the country of origin but likely do not apply to the ability to predict the unique molecules of each country from sequence data alone. To ensure that data accessibility and attribution is maintained, and to avoid the issues with rampant patenting of nucleic acids [45], we are posting data from the consortium and ensuring BGC first-pass detection as a component of standard QC for each sample. 


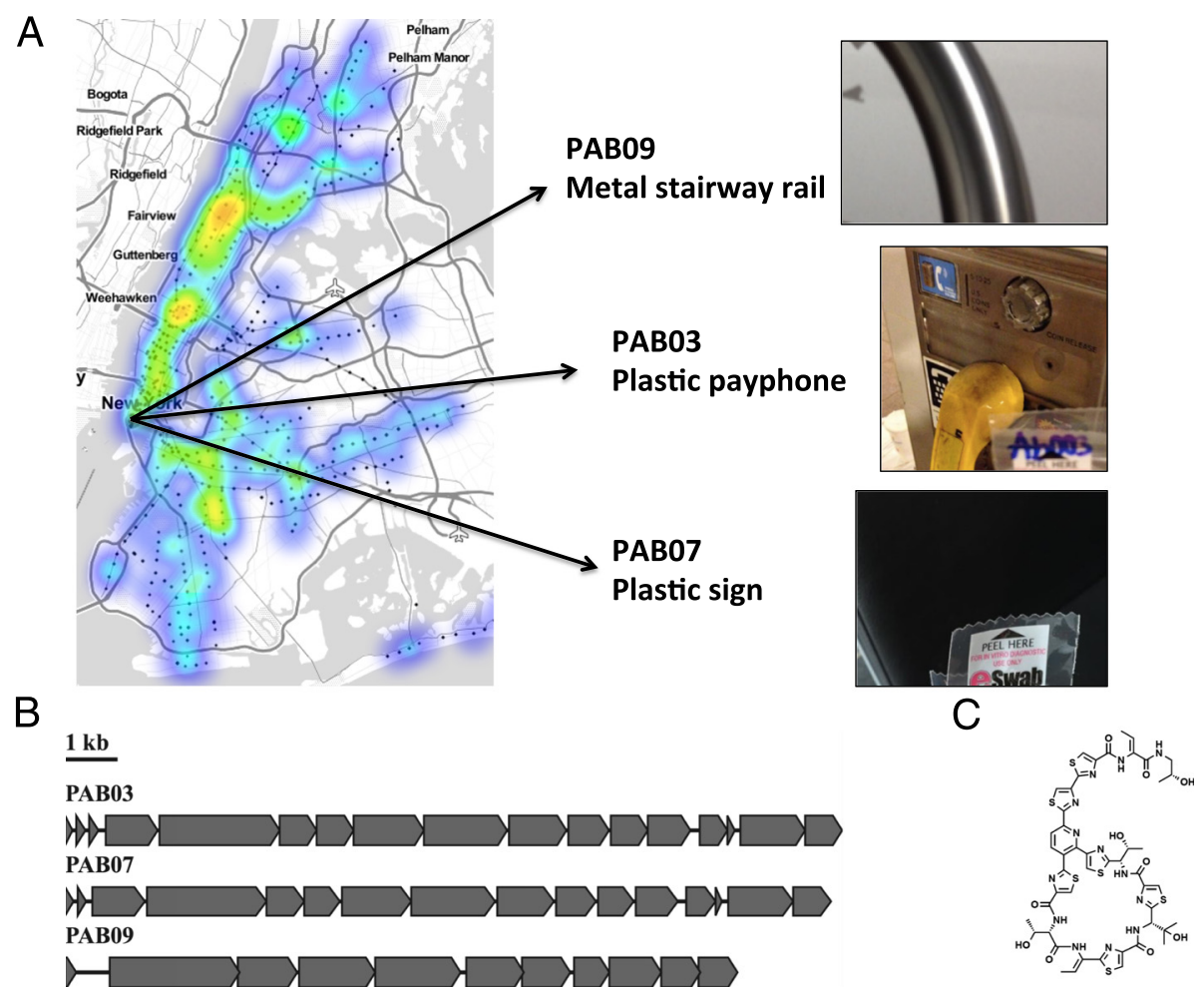

Fig. 3 Discovery of biosynthetic gene clusters from surface-based metagenomics sampling. Plotting the density of organisms across the city shows many diverse sites from which new biology could be discovered red to purple from highest to lowest); plotted here is the Pseudomonas genus, and examples of three samples from the NYC PathoMap study: PAB009 (stairway railing), PAB03 (payphone), and PAB07 (sign). b Three predicted BGCs discovered in the corresponding samples shown in a. Interestingly, these three BGCs are predicted to encode known and novel small molecules of the thiopeptide/thiocillin class of antibiotics.

\section{Study design and goals}

The final part of the meeting was to define the goals of the MetaSUB consortium, which is now planned for at least five years (2016-2020) and rooted in five core areas: collection, analysis, design, standards, and education.

\section{Collection}

Establishing a coordinated, global data collection is slated to begin on June 21, 2016, to match and parallel the Global Ocean Sampling Day (OSD) [46, 47]. The will begin the seasonal of cities around the world for the next five years, matching at least the once-a-year frequency of (OSD), but each season if possible for each city. Notably, this time frame overlaps both the Brazilian and Japanese Olympics, generating the profile of a city's "olympiome," representing a first-ever sampling of cities before, during, and after a global human migration event. Sampling will be done to include: air in public parks, surfaces in subway or transit system kiosks, park water fountains, and adjacent ocean water (through OSD). Also, a subset of 50 samples will undergo some single-cell and cross-linked read capture ( $\mathrm{Hi}-\mathrm{C})$, and longread sequencing for improved species resolution. Sampling will focus on areas of mass transit, but other areas throughout the city will be considered in order to paint a clearer molecular portrait of the city and explore potential networks and feedback mechanisms that may exist.

\section{Analysis}

There will be ongoing work for testing, sharing, and advancing computational methods. Also, we will link to and curate a global database of detected BGCs as well as antimicrobial resistance (AMR) markers. We will also use rarefaction plots and Shannon diversity indices to create cross-kingdom (plant, animal, bacterial, viral) measures of diversity between climates and cities. Finally, we will look for any evidence of horizontal gene transfer (HGT) in the samples when comparing to newly sequenced genomes from local areas.

\section{Design}

These methods of collection that characterize many types of surfaces may have an impact on future designs and types of transit systems. There, collections include samples from many types of surfaces, including plastic, cloth, metal, ceramic, glass, and stone. In addition, we will collect metadata about temperature, humidity, volatile organic carbons (VOCs), air components, and other 
environmental parameters. A long-term goal of the consortium would be to design surfaces to enhance the "good bacteria" present such that they could outcomplete the "bad bacteria" and make the surfaces better for human occupancy and transit.

\section{Standards}

By deploying and testing DNA and bioinformatics standards, we will help improve methods in the field of metagenomics. Specifically, we will continue to use samples with known proportions of species for in silico measurement and testing of algorithms [1]. Also, we will use Genome Reference Consortium (GRC) and US National Institute of Standards and Technology (NIST) standards for future testing of sequencing methods. Finally, we will plan to develop synthetic oligonucleotides for positive controls during sampling to address the question of DNA/RNA bias during collection.

\section{Education}

Using our methods for outreach, education, and handson training is one of the key components of the consortium. We have already engaged hundreds of students in cities associated with the MetaSUB Consortium study, and we intend to maintain this educational component. This will include some citizen science outreach for high school, college, graduate, and medical students, as well as credits for a related course (microbiology, ecology, genetics, genomics) during the sampling expeditions ("swabventure"). Also, we have started a study abroad and lab exchange program so that members of the Consortium can visit each other's labs and sites to learn about genomics, informatics, or architecture. Indeed, we already have three artists in residence for the Consortium, all of whom work to visualize the microscopic and metagenomic world around us. Finally, we will build a program to enable a certificate of molecular microscopy, ideally as a free, online course for people to take in their own country.

\section{Community outreach}

Along with the educational goals, MetaSUB seeks to interact with local communities, teaching others to explore the microbiome that lives in us, on us, and all around us [46]. We believe in the freedom of information and feel that citizens are entitled to know about the environment in which they live. We encourage citizens to propose certain sites to be profiled, as well as encourage their involvement in the sampling process. Our Global City Sampling Day (CSD) will be driven not only by scientists in the consortium but open to all citizens interested in exploring the molecular microbial and metagenomic dynamics of their cities and oceans (with OSD). We also feel that it is important to provide easy access to the data collected in a way that enables meaningful interpretations by the general public. We hope that residents will have a role in disseminating and discussing the results and that we will provide an additional metric with which to understand and explore our urban environment.

\section{Conclusion}

Working together, we are building an unprecedented, global metagenomics dataset and molecular portrait of the urban microbiomes that we all share. Our collective efforts aim to help current and future work in city planning, urban design and architecture, transit systems, public health, ecological studies, genome technologies, and improved understanding of cities. We aim to use the lessons of the preliminary studies to highlight the richness of the microbial ecosystems of cities, train new students in best practices and methods for metagenomics and microbiome analysis, and ensure the greatest utility and benefit of these data. These data will also provide a novel resource to discover new biochemical pathways, sources of antimicrobial resistance, new methods of metagenomic design, and new antibiotics that are created by the ecosystem of microbes that have evolved to live among us (and we among them).

\begin{abstract}
Abbreviations
AMR: antimicrobial resistance; BGCs: biosynthetic gene clusters; CTSC: Clinical and Translational Science Center; EAB: external advisory board;

EGA: European Genome-phenome Archive; EMP: Earth Microbiome Project; FDA: Food and Drug Administration; GEO: Gene Expression Omnibus; GRC: Genome Reference Consortium; HGT: horizontal gene transfer; HMP: Human Microbiome Project; MetaSUB: Metagenomics and Metadesign of Subways and Urban Biomes; MIAME: Minimum Information About a Microarray Experiment; NIST: National Institute of Standards and Technology; NYC: New York City; NYGC: New York Genome Center; OSBSS: open source building science sensors; PI: principal investigator; SAGE: SAGE Bionetworks; SEQC: Sequencing Quality Control Consortium; TCGA: The Cancer Genome Atlas; VOCs: volatile organic carbons.
\end{abstract}

\section{Acknowledgements}

We would like to thank the Alfred P. Sloan Foundation (2015-13964) and in particular, Paula Olsiewski, for her insightful guidance during the founding of the Consortium, and for the Alfred P. Sloan Foundation's generous support in funding the MetaSUB planning meetings and conferences. Moreover, the Bill and Melinda Gates Foundation's Grand Challenges Exploration grant helped generate the sequence data for the first global city sampling day (CSD). We also wanted to thank Jeff Zhu and the Clinical and Translational Science Center (CTSC). We would also like to thank the Irma T. Hirschl and Monique Weill-Caulier Charitable Trusts, the WorldQuant Foundation, the Bert $\mathrm{L}$ and N Kuggie Vallee Foundation, the STARR Consortium (17-A765, 19-A9071), and support from the National Institutes of Health (F31GM111053, R01NS076465, and R25EB020393). We also would like to thank Promega, CosmosID, Illumina, Copan, and QIAGEN that sponsored the inaugural MetaSUB 2015 meeting, including travel grants for many of the participants. We would like to thank Diana Stern for her dedication and immeasurable help planning and organizing the inaugural conference as well as the New York Genome Center (Nathan Pearson and Jennifer Busuttil-Doran) for hosting the conference. We also want to thank the eXtreme Mcirobiome Project (XMP), the Association of Biomolecular Resource Facilities (ABRF) Metagenomics Research Group (MGRG), and George Yeh. This work was also supported in part by the National High Technology Research and Development Program of China (2015AA020104), the National Natural Science Foundation of China (31471239) and the 111 Project (B13016).

Consortium Lead: Christopher E. Mason

Executive Directors: Ebrahim Afshinnekoo and Sofia Ahsanuddin 
External Advisory Board (EAB): Elodie Ghedin, Timothy Read, Claire Fraser, Joel Dudley, Mark Hernandez, and Christopher Bowler

MetaSUB Consortium Members: Ariel Chernomoretz and Gustavo Stolovitzky (Buenos Aires, Argentina), Paweł P Łabaj \& Alexandra B. Graf (Vienna, Austria), Aaron Darling and Catherine Burke (Sydney, Australia), Houtan Noushmehr (Ribeirão Preto, Brasil), Emmanuel Dias-Neto (São Paulo, Brazil), Yongli Guo (Beijing, China), Zhi Xie (Guangzhou, China), Patrick Lee (Hong Kong, China), Leming Shi (Shanghai, China), Carlos A. Ruiz-Perez and Maria Mercedes Zambrano (Bogota, Colombia), Rania Siam and Amged Ouf (Cairo, Egypt), Hugues Richard and Ingrid Lafontaine (Paris, France), Lothar H. Wieler and Torsten Semmler (Berlin, Germany), Bharath Prithiviraj, and Narasimha Nedunuri (Hyderabad, India), Shaadi Mehr and Kambiz Banihashemi (Tehran, Iran), Florigio Lista and Anna Anselmo (Rome, Italy), Haruo Suzuki, Makoto Kuroda, Riu Yamashita, Yukoto Sato, Eli Kaminuma (Tokyo and Sendai Japan), Celia M. Alpuche Aranda and Jesus Martinez (Mexico City, Mexico), Christopher Dada (Auckland, Hamilton and Rotorua, (New Zealand)), Marius Dybwad (Oslo, Norway), Manuela Oliveira (Lisbon, Portugal and Porto, Portugal), Stephan Schuster (Singapore, Singapore), Geoffrey H. Siwo (Johannesburg, South Africa), Soojin Jang, Sung Chul Seo, and Sung Ho Hwang (Seoul, South Korea), Stephan Ossowski and Daniela Bezdan (Barcelona, Spain), Salama Chaker and Aspassia D. Chatziefthimiou (Doha, Qatar), Klas Udekwu and Per Liungdahl (Stockholm, Sweden), Ugur Sezerman and Cem Meydan (Izmir, Turkey), Eran Elhaik (Sheffeild, UK), Gaston Gonnet (Montevideo, Uruguay), Lynn M. Schriml and Emmanuel Mongodin (Baltimore, USA and Washington D.C., USA), Curtis Huttenhower (Boston, USA), Jack Gilbert (Chicago, USA), Christopher E. Mason (New York City, USA), Jonathan Eisen (Sacramento and San Francisco, USA), David Hirschberg (Seattle, USA), Mark Hernandez (Denver, USA), Ken McGrath and Leanne McGrath (Brisbane, Australia), Andrew Gray (Melbourne, Australia), Olayinka Osuolale (Ilorin, Nigeria), Nicola Segata (Trenton, Italy), Silvia Fillo (Rome, Italy), Gregorio Iraola (Montevideo, Uruguay), Yiming Zhou (Beijing, China), Yujun Chang (Beijing, China), Yang Li (Beijing, China), Yuanting Zhend (Shanghai, China), Wanwan Hou (Shanghai, China), Adan Ramirez (Bogota, Colombia), Martha Cepeda (Bogota, Colombia), Christelle Desnues (Marseille, France), Nicolas Rascovan (Marseille, France), Colin Baron (Düsseldorf, Germany), Niranjan Nagarajan (Singapore), Danilo Ercolini (Naples, Italy), Wayne Menary (Lima, Peru), Scott Tighe (Vermont, USA), Mohamed Donia (Princeton, USA), Shawn Levy (Huntsville, USA), Joseph Benito (Huntsville, USA), Angela Jones (Huntsville, USA)

Inaugural MetaSUB International Meeting Speakers: Jack Gilbert*, Curtis Huttenhower*, Andrew Kasarskis*, Patrick Lee, Christopher E. Mason, Julia Maritz, Ellen Jorgensen, Scott Tighe, Russell Neches, Tom Livelli, Leming Shi, Houtan Noushmehr, Haruo Suzuki, Jesus Martinez Barnetche, Catherine Burke, Aaron Darling, Hugues Richard, Zhi Xie, Stephan Ossowski, Edoardo Pasolli, Nick Greenfield, Nur Hasan, Ebrahim Afshinnekoo, Mohamed Donia, John Brownstein, Linda Nozick, Harold Michels, Lynn Schriml, Catherine Brownstein, Jeanne Garbarino, Abby Lyons, and Jeff Zhu

* denotes keynote address

For more details on these speakers including their biographies, talk titles, and slides please visit http://www.metasub.org/2015.html

Manuscript Lead: Ebrahim Afshinnekoo

The following authors contributed to this manuscript: Ebrahim Afshinnekoo, Sofia Ahsanuddin, Emmanuel Dias-Neto, Brian Kidd, Daniela Bezdan, Scott Tighe, Elizabeth Hénaff, Mohamed Donia, Lynn Schriml, Christopher E. Mason, and George Yeh, Millipore Sigma

Website Curator: Sofia Ahsanuddin

Corresponding author: Christopher E. Mason

\section{Authors' contributions}

All authors read and approved the final manuscript.

\section{Competing interests}

The authors declare that they have no competing interests.

Received: 17 December 2015 Accepted: 15 April 2016 Published online: 03 June 2016

\section{References}

1. The MetaSUB International Consortium: The Metagenomics and Metadesign of the Subways and Urban Biomes (MetaSUB) International Consortium inaugural meeting report. Microbiome 2016;4:24.
2. Leung MH, Wilkins D, Li EK, Kong FK, Lee PK. Indoor-air microbiome in an urban subway network: diversity and dynamics. Appl Environ Microbiol. 2014;80:6760-70.

3. Robertson CE, Baumgartner LK, Harris JK, Peterson KL, Stevens MJ, Frank DN, Pace NR. Culture-independent analysis of aerosol microbiology in a metropolitan subway system. Appl Environ Microbiol. 2013;79(11):3485-93.

4. Cao C, Jiang W, Wang B, Fang J, Lang J, Tian G, Jiang J, Zhu TF. Inhalable microorganisms in Beijing's PM2.5 and PM10 pollutants during a severe smog event. Environ Sci Technol. 2014;48(3):1499-507.

5. Yooseph S, Andrews-Pfannkoch C, Tenney A, McQuaid J, Williamson S, Thiagarajan M, Brami D, Zeigler-Allen L, Hoffman J, Goll JB, Fadrosh D, Glass J, Adams MD, Friedman R, Venter JC. A metagenomic framework for the study of airborne microbial communities. PLoS One. 2013;8(12):e81862.

6. Firth C, Bhat M, Firth MA, Williams SH, Frye MJ, Simmonds P, Conte JM, Ng J, Garcia J, Bhuva NP, Lee B, Che X, Quan PL, Lipkin WI. Detection of zoonotic pathogens and characterization of novel viruses carried by commensal Rattus norvegicus in New York City. MBio. 2014;5(5):e01933-14.

7. Conceição T, Diamantino F, Coelho C, de Lencastre H, Aires-de-Sousa M. Contamination of public buses with MRSA in Lisbon, Portugal: a possible transmission route of major MRSA clones within the community. PLoS One. 2013;8(11):e77812.

8. Reese AT, Savage A, Youngsteadt E, McGuire KL, Koling A, Watkins O, Frank $\mathrm{SD}$, Dunn RR. Urban stress is associated with variation in microbial species composition-but not richness-in Manhattan. ISME J. 2015;10:751-60. doi:10.1038/ismej.2015.152.

9. Alivisatos AP, Blaser MJ, Brodie EL, Chun M, Dangl JL, Donohue TJ, Dorrestein PC, Gilbert JA, Green JL, Jansson JK, Knight R, Maxon ME, McFallNgai MJ, Miller JF, Pollard KS, Ruby EG, Taha SA; Unified Microbiome Initiative Consortium. A unified initiative to harness Earth's microbiomes. Science. 2015;350(6260):507-8.

10. Dubilier N, McFall-Ngai M, Zhao L. Microbiology: create a global microbiome effort. Nature. 2015;526(7575):631-4.

11. Jones MB, Highlander SK, Anderson EL, Li W, Dayrit M, Klitgord N, abani MM, Seguritan V, Green J, Pride DT, Yooseph S, Biggs W, Nelson KE, Venter JC. Library preparation methodology can influence genomic and functional predictions in human microbiome research. Proc Natl Acad Sci U S A. 2015;112(45):14024-9.

12. Afshinnekoo E, Meydan C, Chowdhury S, Jaroudi D, Boyer C, Bernstein N, Maritz JM, Reeves D, Gandara J, Chhangawala S, Ahsanuddin S, Simmons A, Nessel T, Sundaresh B, Pereira E, Jorgensen E, Kolokotronis S, Kirchberger N, Garcia I, Gandara D, Dhanraj S, Nawrin T, Saletore Y, Alexander N, Vijay P, Hénaff EM, Zumbo P, Walsh M, O'Mullan GD, Tighe S, Dudley J, Dunaif A, Ennis $S$, O'Halloran E, Magalhaes TR, Boone B, Jones AL, Muth TR, Paolantonio KS, Alter E, Schadt EE, Garbarino J, Prill RJ, Carlton JM, Levy S, Mason CE. Modern methods for delineating metagenomic complexity. Cell Sys. 2015;1(1):88.

13. The United Nations (UN). Study of "The 2014 World Urbanization Prospects report". http://esa.un.org/unpd/wup. Accessed 10 July 2014.

14. Schatz MC, Phillippy AM. The rise of a digital immune system. Giga Sci. 2012;1(1):4

15. Mason CE, Porter S, Smith T. Characterizing Multi-omic data in systems biology. Adv Exp Med Biol. 2014;799:15-38.

16. Ji P, Parks J, Edwards MA, Pruden A. Impact of water chemistry, pipe material and stagnation on the building plumbing microbiome. PLoS One. 2015:10(10):e0141087.

17. Slavin K, Perez M, Mir, RF, Woebken C, Najjar D, Henaff E, Mason CE. Holobiont Urbanism and Bees and Citizen Scientists. http://microbiome.nyc

18. Donia MS, Cimermancic P, Schulze CJ, Wieland Brown LC, Martin J, Mitreva $M$, Clardy J, Linington RG, and Fischbach MA. A systematic analysis of biosynthetic gene clusters in the human microbiome reveals a common family of antibiotics. Cell. 2014;158:1402-14.

19. Rosenfeld JA, Reeves D, Brugler MR, Narechania A, Simon S, Durrett R, Foox J, Shianna K, Schatz MC, Gandara J, Afshinnekoo E, Lam ET, Hastie AR, Chan S, Cao H, Saghbini M, Kentsis A, Planet PJ, Kholodovych V, Tessler M, Baker R, DeSalle R, Sorkin LN, Kolokotronis, Siddall ME, Amato G, Mason CE. Genome assembly and geospatial phylogenomics of the bed bug Cimex lectularius. Nat Commun. 2016;7, 10164. doi:10.1038/ncomms10164.

20. Li S, Mason CE. The pivotal regulatory landscape of RNA modifications. Annu Rev Genomics Hum Genet. 2014;15:127-50.

21. Traxler MF, Kolter R. Natural products in soil microbe interactions and evolution. Nat Prod Rep. 2015;32:956-70.

22. Hu Y, Phelan V, Ntai I, Farnet CM, Zazopoulos E, Bachmann BO. Benzodiazepine biosynthesis in Streptomyces refuineus. Chem Biol. 2007;14:691-701. 
23. Dimise EJ, Widboom PF, Bruner SD. Structure elucidation and biosynthesis of fuscachelins, peptide siderophores from the moderate thermophile Thermobifida fusca. Proc Natl Acad Sci U S A. 2008;105:15311-6.

24. Ehrenberg R. Urban microbe come out of the shadows. Nature. 2015;522:399-400. doi:10.1038/522399a.

25. Patel, R., "Scientists are studying subway germs to keep us healthier." Popular Science 2015. http://www.popsci.com/scientists-are-studyingsubway-germs-keep-us-healthier

26. Hsu T, Joice R, Vallarino J, Abu-Ali G, Hartmann EM, Shafquat A, Dulong C, Baranowski C, Gevers D, Green JL, Morgan XC, Spengler JD, Huttenhower C. Urban transit system microbial communities differ by surface type and interaction with humans and environment. In Press

27. The FDAs SEQC/MAQC-III Consortium, Mason CE, Shi L. A comprehensive assessment of RNA-seq accuracy, reproducibility and information content by the Sequence Quality Control consortium. Nature Biotech. 2014:32(9):903-14.

28. Pendleton M, Sebra R, Pang AW, Ummat A, Franzen O, Rausch T, Stütz AM, Stedman W, Anantharaman T, Hastie A, Dai H, Fritz MH, Cao H, Cohain A, Deikus G, Durrett RE, Blanchard SC, Altman R, Chin CS, Guo Y, Paxinos EE, Korbel JO, Darnell RB, McCombie WR, Kwok PY, Mason CE, Schadt EE, Bashir A. Assembly and diploid architecture of an individual human genome via single-molecule technologies. Nat Methods. 2015:29.

29. Zook J et al. Extensive sequencing of seven human genomes to characterize benchmark reference materials. Sci Data. 2016. doi:10.1101/026468.

30. Gilbert JA, Jansson JK, Knight R. The Earth Microbiome project: successes and aspirations. BMC Biol. 2014;12(1):69.

31. Filippidou S, Junier T, Wunderlin T, Lo CC, Li PE, Chain PS, Junier P. Under-detection of endospore-forming firmicutes in metagenomic data. Comput Struct Biotechnol J. 2015;13:299-306. doi:10.1016/j.csbj. 2015.04.002.

32. Vieira-Silva S, Rocha EP. The systemic imprint of growth and its uses in ecological (meta)genomics. PLoS Genet. 2010;6(1):e1000808. doi:10.1371/ journal.pgen.1000808.

33. Felczykowska A, Krajewska A, Zielińska S, Los JM. Sampling, metadata and DNA extraction-important steps in metagenomic studies. Acta Biochim Pol. 2015;62(1):151-60. doi:10.18388/abp.2014_916.

34. Li S, Tighe SW, Nicolet CM, Grove D, Levy S, Farmerie W, Viale A, Wright C, Schweitzer PA, Gao, Kim D, Boland J, Hicks B, Kim R, Chhangawala S, Jafari D, Raghavachari N, Gandara J, Garcia-Reyero N, Hendrickson C, Roberson D, Rosenfeld JA, Smith T, Underwood JG, Wang M, Zumbo P, Baldwin DA, Grills GS, Mason CE. Multi-platform assessment of transcriptome profiling using RNA-Seq in the ABRF Next Generation Sequencing Study. Nat Biotechnol. 2014;32(9):915-25.

35. Cameron P, Corne DW, Mason CE, Rosenfeld J. Crowdfunding genomics and bioinformatics. Genome Biol. 2013;14(9):134.

36. Li S, Labaj P, Zumbo R, Shi W, Phan J, Wu L, Wang M, Thierry-Mieg J, Thierry-Mieg D, Shi L, Kreil D, Mason CE. Detecting and correcting systematic variation from large-scale RNA sequencing. Nat Biotechnol. 2014;32(9):888-95. PMID: 25150837

37. Dudley JT, Butte AJ. In silico research in the era of cloud computing. Nat Biotechnol. 2010;28(11):1181-5.

38. Fisch KM, Meißner T, Gioia L, Ducom JC, Carland TM, Loguercio S, Su Al. Omics Pipe: a community-based framework for reproducible multi-omics data analysis. Bioinformatics. 2015;31(11):1724-8.

39. La Rosa PS, Brooks JP, Deych E, Boone EL, Edwards DJ, Wang Q, Sodergren E, Weinstock G, Shannon WD. Hypothesis testing and power calculations for taxonomic-based human microbiome data. PLoS One. 2012;7(12):e52078.

40. http://www.ncbi.n/m.nih.gov/geo/

41. Ilkka L, Almeida-King J, Kumanduri V, Senf A, Spalding JD, Ur-Rehman S, Saunders G, Kandasamy J, Caccamo M, Leinonen R, Vaughan R, Laurent T, Rowland F, Marin-Garcia P, Barker J, Jokinen P, Torres AC, Rambla De Argila J, Llobet OM, Medina I, Puy MS, Alberich M, De La Torre S, Navarro A, Paschall J, Flicek P. The European Genome-phenome Archive of human data consented for biomedical research. Nat Genet. 2015;47(7):692-95.

42. Brazma A, Hingamp P, Quackenbush J, Sherlock G, Spellman P, Stoeckert C, Aach J, Ansorge W, Ball CA, Causton HC, Gaasterland T, Glenisson P, Holstege FC, Kim IF, Markowitz V, Matese JC, Parkinson H, Robinson A, Sarkans U, Schulze-Kremer S, Stewart J, Taylor R, Vilo J, Vingron M. Minimum information about a microarray experiment (MIAME)-toward standards for microarray data. Nat Genet. 2001;29(4):365-71.

43. Rung J, Brazma A. Reuse of public genome-wide gene expression data. Nat Rev Genet. 2013;14(2):89-99.
44. Piwowar HA, Vision TJ, Whitlock MC. Data archiving is a good investment. Nature. 2011;473(7347):285.

45. Rosenfeld J, Mason CE. Pervasive sequence patents cover the entire human genome. Genome Med. 2013:5(3):27. PMID: 23522065.

46. Kopf A, Bicak M, Kottmann R, Schnetzer J, Kostadinov I, Lehmann K, Fernandez-Guerra A, Jeanthon C, Rahav E, Ullrich M, Wichels A, Gerdts G, Polymenakou P, Kotoulas G, Siam R, Abdallah RZ, Sonnenschein EC, Cariou T, O'Gara F, Jackson S, Orlic S, Steinke M, Busch J, Duarte B, Caçador I, Canning-Clode J, Bobrova O, Marteinsson V, Reynisson E, Loureiro CM, Luna GM, Quero GM, Löscher CR, Kremp A, DeLorenzo ME, Øvreås L, Tolman J, LaRoche J, Penna A, Frischer M, Davis T, Katherine B, Meyer CP, Ramos S, Magalhães C, Jude-Lemeilleur F, Aguirre-Macedo ML, Wang S, Poulton N, Jones S, Collin R, Fuhrman JA, Conan P, Alonso C, Stambler N, Goodwin K, Yakimov MM, Baltar F, Bodrossy L, Van De Kamp J, Frampton DM, Ostrowski M, Van Ruth P, Malthouse P, Claus S, Deneudt K, Mortelmans J, Pitois S, Wallom D, Salter I, Costa R, Schroeder DC, Kandil MM, Amaral V, Biancalana F, Santana R, Pedrotti ML, Yoshida T, Ogata H, Ingleton T, Munnik K, Rodriguez-Ezpeleta N, Berteaux-Lecellier V, Wecker P, Cancio I, Vaulot D, Bienhold C, Ghazal H, Chaouni B, Essayeh S, Ettamimi S, Zaid el H, Boukhatem N, Bouali A, Chahboune R, Barrijal S, Timinouni M, El Otmani F, Bennani M, Mea M, Todorova N, Karamfilov V, Ten Hoopen P, Cochrane G, L'Haridon S, Bizsel KC, Vezzi A, Lauro FM, Martin P, Jensen RM, Hinks J, Gebbels S, Rosselli R, De Pascale F, Schiavon R, Dos Santos A, Villar E, Pesant S, Cataletto B, Malfatti F, Edirisinghe R, Silveira JA, Barbier M, Turk V, Tinta T, Fuller WJ, Salihoglu I, Serakinci N, Ergoren MC, Bresnan E, Iriberri J, Nyhus PA, Bente E, Karlsen HE, Golyshin PN, Gasol JM, Moncheva S, Dzhembekova N, Johnson Z, Sinigalliano CD, Gidley ML, Zingone A, Danovaro R, Tsiamis G, Clark MS, Costa AC, El Bour M, Martins AM, Collins RE, Ducluzeau AL, Martinez J, Costello MJ, Amaral-Zettler LA, Gilbert JA, Davies N. Field D, Glöckner FO. The ocean sampling day consortium. Giga Sci. 2015;4:27.

47. Garbarino J, Mason CE. The power of engaging citizen scientists for scientific progress. J Microbiol Biol Educ. 2016;17(1):7-12. doi:10.1128/jmbe. v17i1.1052.

\section{Submit your next manuscript to BioMed Central and we will help you at every step:}

- We accept pre-submission inquiries

- Our selector tool helps you to find the most relevant journal

- We provide round the clock customer support

- Convenient online submission

- Thorough peer review

- Inclusion in PubMed and all major indexing services

- Maximum visibility for your research

Submit your manuscript at www.biomedcentral.com/submit
Ciomed Central 